\title{
Calcitonin gene-related peptide inhibits angiotensin II-mediated vasoconstriction in human radial arteries: Role of the Kir channel
}

\author{
Anthony Zulli, PhD, ${ }^{a, b}$ Bei Ye, MBBS, ${ }^{b}$ Peter J. Wookey, PhD, ${ }^{a, b}$ Brian F. Buxton, MBMS, FRACP, \\ and David L. Hare, MDDS, DPM, FRACPa,b
}

Objective: The radial artery is increasingly used for coronary artery bypass grafts, but its potential for spasm increases postoperative risk. Alpha-calcitonin gene-related peptide is a potent antihypertensive peptide.

Thus, we set out to determine whether calcitonin gene-related peptide can impair angiotensin II-mediated vasoconstriction in human radial arteries and, if so, to determine its mechanism of action.

Methods: Radial arteries were placed in organ bath chambers and preincubated with $10^{-9}$ to $10^{-7} \mathrm{~mol} / \mathrm{L}$ alpha-calcitonin gene-related peptide for 20 minutes before initiating an angiotensin II dose response curve $\left(10^{-10}-10^{-6} \mathrm{~mol} / \mathrm{L}\right)$.

Results: Calcitonin gene-related peptide, $10^{-7}, 10^{-8}, 3 \times 10^{-9}$, and $10^{-9} \mathrm{~mol} / \mathrm{L}$, reduced angiotensin II-mediated vasoconstriction to $30.5 \% \pm 7.2 \%(P<.001), 32.2 \%$ $\pm 11.7 \%(P<.001), 62.6 \% \pm 8.4 \%(P<.001)$, and $77.6 \% \pm 6.7 \%(P<.01)$, respectively, compared with control (normalized to 100\%). Calcitonin gene-related peptide also significantly decreased basal vascular tension in human radial arteries $(P<.05$ in all cases). $N$-nitro-L-arginine methyl ester, 4-aminopyridine, charybdotoxin, and apamin had no effect on calcitonin gene-related peptide relaxation, but $\mathrm{Ba}^{2+}$ impaired the effects of alpha-calcitonin gene-related peptide.

From the Department of Medicine, ${ }^{\text {a }}$ University of Melbourne, Austin Health, Heidelberg, and the Departments of Cardiology ${ }^{\mathrm{b}}$ and Cardiac Surgery, ${ }^{\mathrm{c}}$ Austin Health, Heidelberg, Victoria, Australia.

This project was supported in part by the Austin Hospital Medical Research Foundation, the National Heart Foundation of Australia, and the National Health \& Medical Research Council.

Received for publication July 10, 2007; revisions received Nov 16, 2007; accepted for publication Dec 7, 2007.

Address for reprints: Dr Anthony Zulli, Vascular Biology Laboratory, Department of Cardiology, Austin Health, Heidelberg 3084, Australia (E-mail: azulli@unimelb. edu.au).

J Thorac Cardiovasc Surg 2008;136:370-5 $0022-5223 / \$ 34.00$

Copyright $\odot 2008$ by The American Association for Thoracic Surgery

doi:10.1016/j.jtcvs.2007.12.064
Conclusions: Alpha-calcitonin gene-related peptide dose dependently impaired angiotensin II-mediated vasoconstriction in human radial arteries, independent of nitric oxide and all potassium channels except the barium-sensitive Kir channel. Thus, calcitonin gene-related peptide is an endogenous inhibitor of angiotensin II-mediated vasocontriction in the human radial artery.

$\mathrm{R}$ adial arteries are being used more frequently as coronary artery bypass grafts. However, radial arteries are prone to spasm and thus increase the risk of graft failure. ${ }^{1}$ Angiotensin II (ang II) is an active component of the renin-angiotensin system, which, through its receptor (AT1R), plays an important role in the control of vasoconstriction, cell growth and apoptosis, cell migration, and extracelluar matrix deposition, events that are involved in cardiovascular disease. ${ }^{2}$ On the other hand, calcitonin gene-related peptide (CGRP) is an inhibitor of cell growth and a potent endothelium-independent vasodilator, ${ }^{3-5}$ thus suggesting that it could inhibit ang II-mediated effects. Indeed, long-term ang II infusion is accompanied by an increase in CGRP receptor expression in mesenteric arteries but not in CGRP levels in plasma. ${ }^{6}$ $\alpha$ CGRP is a 37-amino acid peptide, produced by tissue-specific alternative splicing of the primary transcript of the calcitonin $/ \alpha$ CGRP gene. ${ }^{7}$ A second CGRP isoform, BCGRP, is encoded by a different gene locus and is localized almost exclusively to specific neuronal sites. ${ }^{8}$ These two CGRP isoforms $-\alpha$ and $\beta$ in rats and I and II in humans-exhibit overlapping biological activities in most vascular beds, ${ }^{9}$ but $\alpha$ CGRP appears to be regulated by nitric oxide (NO). ${ }^{10}$ CGRP has complex cardiovascular actions. For example, the intramuscular gene transfer of CGRP inhibits neointimal hyperplasia after balloon injury in the rat abdominal aorta, ${ }^{11}$ possibly by 


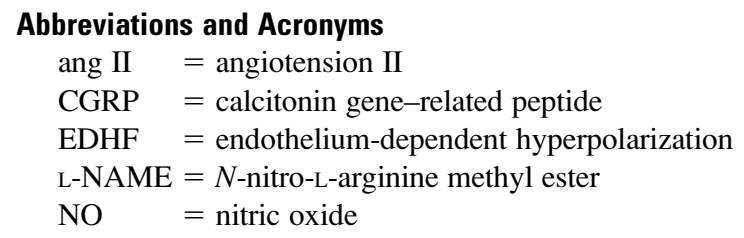

affecting the NO system ${ }^{10,11}$ and the proliferation of vascular smooth muscle cells induced by fetal bovine serum. ${ }^{12}$ More important, CGRP can act directly on smooth muscle cells and stimulate relaxation independently of endothelial function in porcine coronary arteries. ${ }^{3}$ Inasmuch as CGRP can induce vasorelaxation independently of endothelial function and CGRP appears to counteract ang II vasoconstriction in animal models, we sought to determine whether such effects extend to human arteries. To this end, we have used human radial arteries with impaired endothelial function to test the direct effects of CGRP on ang II-mediated vasoconstriction.

\section{Methods}

Discarded distal segments of radial arteries ${ }^{13}$ were obtained from 25 patients undergoing coronary artery bypass grafting using the "open" technique for harvesting. Patients aged 48 to 70 years gave informed consent and were receiving 3-hydroxy-3-methylglutaryl coenzyme A reductase inhibitors, angiotensin-converting enzyme inhibitors, nitrates, and beta adreno-receptor blockers. Patients receiving angiotensin receptor blockers were excluded from this study. Only nontraumatized vessel segments were used in this study. This study was approved by the Austin Hospital Medical Research Ethics Committee and followed institutional guidelines. Harvesting was performed by techniques previously established in our operating theaters ${ }^{1}$; in particular, the specimens were obtained after intraluminal hydrostatic dilatation with papaverine, which impairs endothelial function.

\section{Isometric Tension Studies}

Blood vessels were cleaned of connective tissue and fat and stored at $4^{\circ} \mathrm{C}$ overnight. Pilot studies in our laboratory show no difference in vessel function between freshly isolated radial artery rings and those kept in overnight $4^{\circ} \mathrm{C}$ storage, as also described elsewhere. ${ }^{14}$ Vessels were then cut into 3-mm rings and sequentially mounted between two metal hooks in organ baths attached to force displacement transducers (Grass FT03; Grass Instrument Co, Quincy, Mass). The baths were filled with Krebs solution, kept at a constant temperature of $37^{\circ} \mathrm{C}$, and continuously bubbled with $95 \%$ oxygen $/ 5 \%$ carbon dioxide. After a 2 -hour equilibration period, the rings were stretched to their optimized tension. This technique allows normalization of vascular rings to a physiologic pressure in vitro compared with in vivo and is the accepted method for isometric tension studies. ${ }^{15,16}$ After another 2-hour equilibration period, Krebs buffer was replaced with high potassium solution (KPSS, $124 \mathrm{mmol} / \mathrm{L} \mathrm{K}^{+}$) to induce maximal constriction. After the rings reached plateau (approximately 8 minutes), the rings were flushed with Krebs solution. After another 2-hour equilibration period, rings were incubated with $10^{-9}$ to $10^{-7} \mathrm{~mol} / \mathrm{L} \alpha \mathrm{CGRP}^{17} 20$ minutes before the initiation of an ang II dose response curve $\left(10^{-10}-10^{-6}\right)$. The vessel equilibration time also served to minimize the effect of patient therapy on vessels. ${ }^{18}$ All experimental data were normalized to control, which was set at $100 \%$.

To determine the influence of potassium channels or NO on the inhibitory effects of CGRP, $N$-nitro-L-arginine methyl ester (LNAME; $10^{-5} \mathrm{~mol} / \mathrm{L}$, to inhibit NO), 4-aminopyridine (3 mmol/L, to inhibit voltage-dependent $\mathrm{K}^{+}$channels), charybdotoxin and apa$\min \left(50 \times 10^{-9} \mathrm{~mol} / \mathrm{L}\right.$ and $3 \times 10^{-7} \mathrm{~mol} / \mathrm{L}$, respectively $)$, to inhibit endothelium-dependent hyperpolarization (EDHF), and calcium-activated $\mathrm{K}^{+}$channels and $10^{-4} \mathrm{~mol} / \mathrm{L}$ barium chloride (to inhibit inwardly rectifying $\mathrm{K}^{+}$channels) where used. These concentrations have been shown to be specific for each potassium channel. ${ }^{19,20}$

\section{Data Analysis}

Data are presented as mean \pm standard error of the mean, where " $n$ " represents the number of independent samples studied. Data from arterial samples are expressed as percent response to $124 \mathrm{mmol} / \mathrm{L}$ $\mathrm{KCl}$. Statistical comparisons were undertaken with either the Student $t$ test or a 1-way analysis of variance (where appropriate) and a $P$ value of .05 using GraphPad Prism software (GraphPad Software, Inc, San Diego, Calif).

\section{Results}

\section{Effects of $\alpha$ CGRP on Ang II-mediated} Vasoconstriction

$\alpha$ CGRP potently inhibited ang II-mediated vasoconstriction at all concentrations used. Both $10^{-7} \mathrm{~mol} / \mathrm{L}$ and $10^{-8} \mathrm{~mol} / \mathrm{L}$ $\alpha$ CGRP inhibited maximal contraction evoked by $10^{-6} \mathrm{~mol} / \mathrm{L}$ ang II by $69 \%(P<.001)$ and $68 \%(P<.001)$, respectively. Indeed, $10^{-7} \mathrm{~mol} / \mathrm{L} \alpha \mathrm{CGRP}$ inhibited ang II-mediated vasoconstriction from $3 \times 10^{-10} \mathrm{~mol} / \mathrm{L}$ [ang II], reducing constriction from $1.56 \% \pm 0.45 \%$ to $-0.62 \% \pm 0.41 \%$ $(P<.05)$. The negative value indicates continued relaxation rather than constriction as seen with the control. The inhibitory effect of $10^{-7} \mathrm{~mol} / \mathrm{L} \alpha \mathrm{CGRP}$ continued to $10^{-9} \mathrm{~mol} / \mathrm{L}$ ang II, reducing constriction from $4.4 \% \pm 1 \%$ to $0.08 \% \pm$ $0.65 \%(P<.05)$. Starting at the lowest concentration of $10^{-9} \mathrm{~mol} / \mathrm{L}$ ang II, $\alpha \mathrm{CGRP}$ concentrations of $3 \times 10^{-9}$, $10^{-8}$, and $10^{-7} \mathrm{~mol} / \mathrm{L}$ all significantly inhibited ang II-mediated vasoconstriction. At a concentration of $10^{-9} \mathrm{~mol} / \mathrm{L}$, $\alpha$ CGRP inhibited ang II-mediated vasoconstriction only at the concentration of $3 \times 10^{-6} \mathrm{~mol} / \mathrm{L}$, by $21 \%(P<.05)$ and at the maximal ang II concentration used, $10^{-6} \mathrm{~mol} / \mathrm{L}$ by $22 \%(P<.01)$ (Figure $1, A)$. There was no difference in maximum contraction evoked by $124 \mathrm{mmol} / \mathrm{L}$ potassium between groups (Figure 1, B).

\section{Effects of $\alpha$ CGRP on Basal Tone}

$\alpha$ CGRP also significantly decreased basal vascular tension in human radial arteries. After the 20-minute period following the addition of $\alpha$ CGRP or vehicle (control), $10^{-7} \mathrm{~mol} / \mathrm{L}$ $\alpha$ CGRP showed the highest decrease in basal tension (expressed as force in grams, Figure 1,C) compared with 

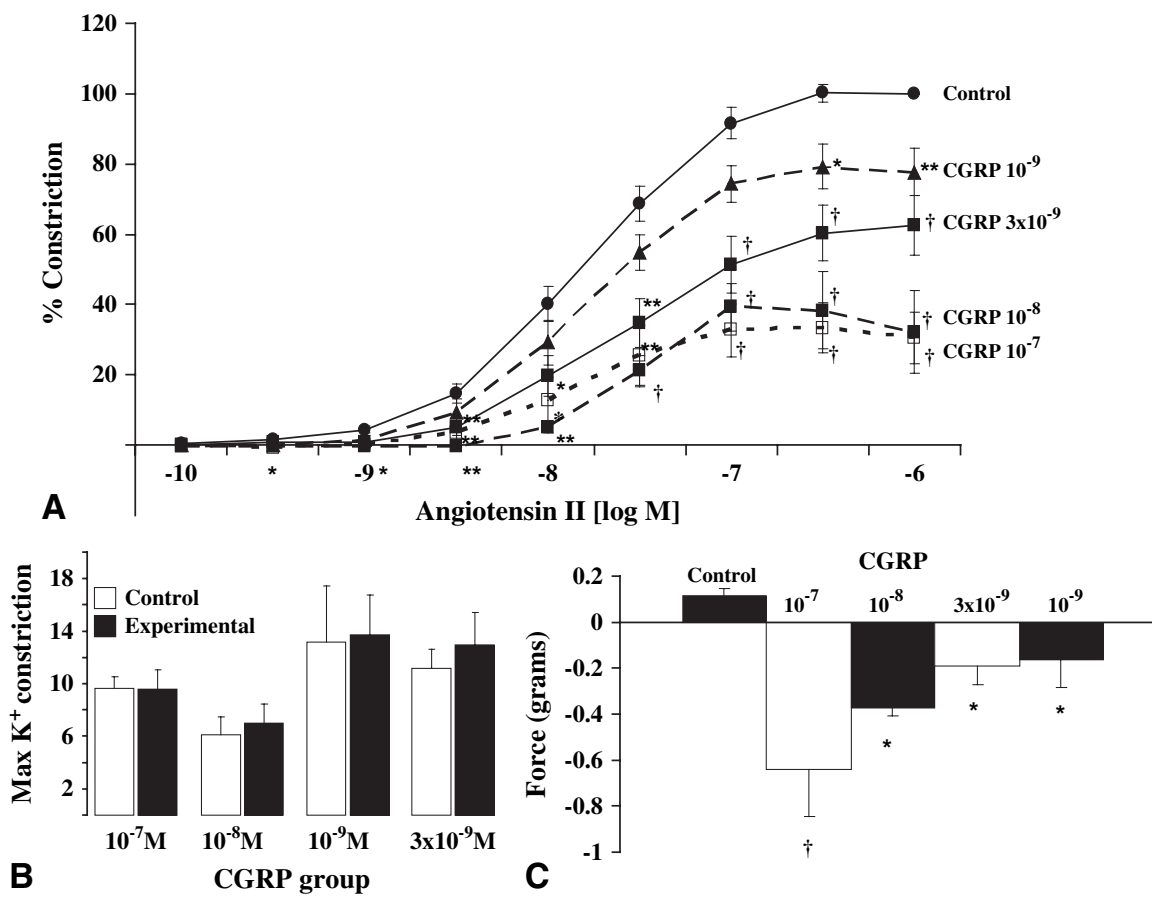

Figure 1. Graph showing the inhibitory effects of CGRP on angiotensin II-mediated vasoconstriction. $A$, CGRP concentrations of $10^{-8} \mathrm{~mol} / \mathrm{L}(\mathrm{n}=5)$ and $10^{-7}$ $\mathrm{mol} / \mathrm{L}(\mathbf{n}=9$ ), inhibition of angiotensin II remained constant at $68 \%$ and $69 \%$, respectively, and did not follow the dose-dependent increase observed for lower concentrations $(\boldsymbol{P}<.001$ in both cases). B, Box plots showing the maximum potassium $\left(K^{+}\right)$constriction per CGRP dose tested. Each experimental dose (closed box) was normalized to its adjacent segment (control, open box), as to restrict variation between segments. There was no difference in the maximum contraction to $124 \mathrm{mmol} /$ $L$ potassium in any group. C, Exposing human radial arteries to increasing concentrations of CGRP has a dose-dependent, albeit slight, dilatory effect on the basal arterial tone of isolated human radial arteries over a 20 -minute period. Results are mean $\pm S E M,{ }^{*} P<.05$, ${ }^{* *} \boldsymbol{P}<.01, \dagger \boldsymbol{P}<.001$. control: $-0.64 \pm 0.2 \mathrm{~g}$ versus $0.11 \pm 0.03 \mathrm{~g}(P<.001)$. This was followed by $10^{-8} \mathrm{~mol} / \mathrm{L} \alpha \mathrm{CGRP}(-0.37 \pm 0.03 \mathrm{~g} ; P<$ $.05), 3 \times 10^{-9} \mathrm{~mol} / \mathrm{L}(-0.19 \pm 0.08 \mathrm{~g} ; P<.05)$, and $10^{-9}$ $\mathrm{mol} / \mathrm{L} \alpha \mathrm{CGRP}(-0.16 \pm 0.12 \mathrm{~g} ; P<.05)$.

\section{Effects of L-NAME on $\alpha$ CGRP-induced Vasodilation}

To determine whether NO release was involved in the effects of CGRP, we added L-NAME to the organ baths 20 minutes before the ang II dose response curve. Then, at $10^{-8} \mathrm{~mol} / \mathrm{L}$ (ang II), $\alpha$ CGRP $\left(10^{-8} \mathrm{~mol} / \mathrm{L}\right)$ was added and $\alpha$ CGRP completely relaxed arteries after approximately 10 minutes. The actual trace is shown in Figure 2, $A$, and the results of 3 independent experiments are shown in Figure 2, $B$.

\section{Effects of $\alpha$ CGRP on Potassium Channels}

To determine whether potassium channels were involved in the effects of $\alpha \mathrm{CGRP}$, we added 4-aminopyridine to the radial artery and vasoconstriction occurred rapidly, an effect that was completely reversed by the addition of $10^{-8} \mathrm{~mol} / \mathrm{L}$ $\alpha$ CGRP but restored by the addition of $\mathrm{ba}^{2+}$ (actual trace shown, Figure 2, $C$ ); the results of 5 independent experiments are shown in Figure 2, D. As well, charybdotoxin plus apamin (Figure 2, $E$ and $F$ )) was added to radial arteries to inhibit endothelium hyperpolarization via the release of EDHF and calcium-activated $\mathrm{K}^{+}$channels. This had no effect on $10^{-8}$ mol/L $\alpha$ CGRP-induced reduction in basal tension, but $\mathrm{Ba}^{2+}$ impaired CGRP effects and induced potent vasoconstriction (actual trace shown, Figure 2,E). The results of 3 in- dependent experiments are shown in Figure 2, F. Moreover, the addition of $\mathrm{Ba}^{2+}$ to radial arteries per se induced vasoconstriction, but the addition of $10^{-8} \mathrm{~mol} / \mathrm{L} \alpha \mathrm{CGRP}$ had no effect (actual trace shown, Figure 2, G). The results of 3 independent experiments are shown in Figure 2, $H$.

\section{Discussion}

This study clearly establishes the importance of $\alpha$ CGRP in influencing radial artery basal tone and desensitizing it to the vasoconstrictive effects of ang II. Furthermore, it was demonstrated that $\alpha$ CGRP-induced vasodilation is preserved in the presence of L-NAME, an NO synthase inhibitor, suggesting that $\alpha \mathrm{CGRP}$ is not dependent on NO for its activity, but could be associated with opening the Kir potassium channel. We further propose that $\alpha \mathrm{CGRP}$ at a concentration of 10 $\mathrm{nmol} / \mathrm{L}$ could be used in preoperative radial artery bath preparations to impair vasospasm and improve postoperative risk.

Growing evidence is indicating that $\alpha$ CGRP and ang II may act reciprocally to help maintain circulatory homeostasis. $^{21-25}$ Our results support this hypothesis, indicating that CGRP acts as a functional antagonist of ang II-mediated vasoconstriction and attenuates vasoconstriction in a dosedependent manner. This result is consistent with previous rat model investigations, which found that CGRP inhibits ang II-induced vasoconstriction. ${ }^{21,22}$ Indeed, the only other comparable study involving human radial arteries also yielded similar results. ${ }^{26}$ 


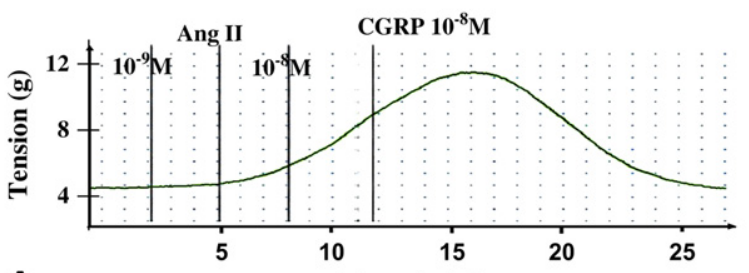

A
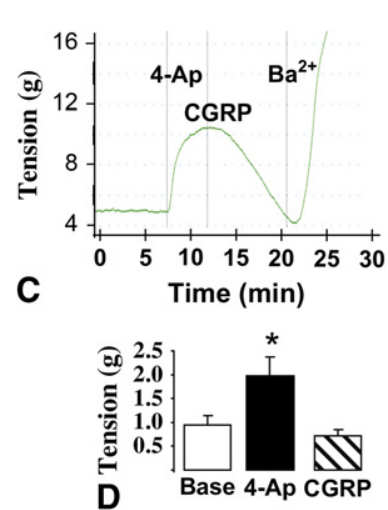

Time (min)
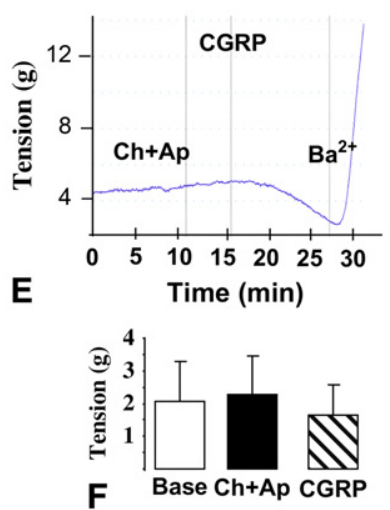
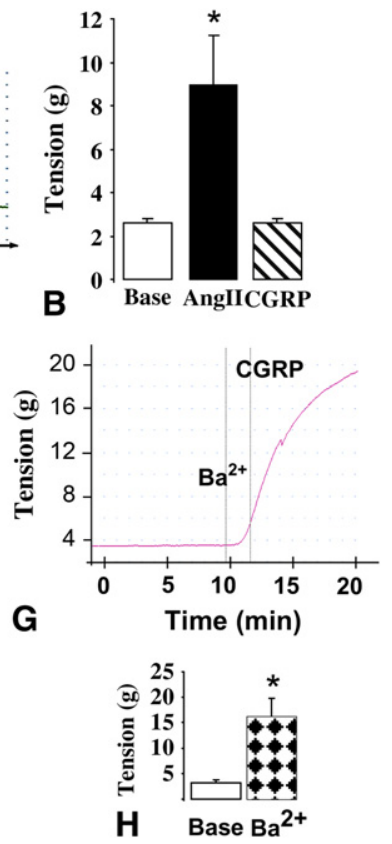

Figure 2. A, Actual trace showing the effects of $10^{-8} \mathrm{~mol} / \mathrm{L} \mathrm{CGRP}$ on ang II-induced vasoconstriction in the presence of $10^{-5} \mathrm{~mol} / \mathrm{L}$ L-NAME. CGRP potently restores normal basal tension after approximately 10 minutes, indicating no effect of nitric oxide on CGRP-induced vasodilation. B, Tabulated results of 3 independent experiments. C, 4-Aminopyridine (4-Ap) was used to block voltage-dependent $\mathrm{K}^{+}$channels, and vasoconstriction occurred immediately after the addition of the drug. CGRP was able to restore basal tension within minutes, but $10^{-4} \mathrm{~mol} / \mathrm{L} \mathrm{Ba}^{2+}$ (Kir inhibitor) caused marked vasoconstriction even in the presence of CGRP. D, Tabulated results of 5 independent experiments. E, Charybdotoxin plus apamin $(\mathrm{Ch}+\mathrm{Ap})$ was added concomitantly to radial arteries to inhibit EDHF and $\mathrm{Ca}^{2+}$-activated $\mathrm{K}^{+}$channels. As shown, $10^{-8} \mathrm{~mol} / \mathrm{L}$ CGRP was able to relax the artery below basal tension, but $10^{-4}$ $\mathrm{mol} / \mathrm{L} \mathrm{Ba}^{2+}$ (Kir inhibitor) caused marked vasoconstriction even in the presence of CGRP. F, Tabulated results of 3 independent experiments. G, The addition of $10^{-4} \mathrm{~mol} / \mathrm{L} \mathrm{Ba}^{2+}$ to radial arteries caused marked vasoconstriction that was not able to be returned to baseline by the addition of $10^{-8} \mathrm{~mol} / \mathrm{L} \mathrm{CGRP,}$ indicating CGRP could act via the Kir channel. H, Tabulated results of 4 independent experiments. Results are mean \pm SEM, ${ }^{*} P<.05$.
Altered vascular $\mathrm{K}^{+}$channel function in cardiovascular disease could be either a cause or consequence of the disease. A current review by Sobey ${ }^{20}$ clearly describes the role of $\mathrm{K}^{+}$ channels in cardiovascular disease. Nevertheless, studies have indicated that current medications used in the treatment of hypertension may already inadvertently involve CGRP and thus open $\mathrm{K}^{+}$channels. Qin and associates ${ }^{27}$ demonstrated that the depressor effects of losartan (ang II receptor antagonist) and perindopril (angiotensin-converting enzyme inhibitor) may be partially mediated via increased synthesis and release of CGRP. Furthermore, the antihypertensive effect of the novel drug rutaercarpine may also be mediated by stimulation of CGRP synthesis and release. ${ }^{28}$ Rutaecarpine is a quinazolinocarboline alkaloid isolated from a widely known Chinese herbal drug Wu-chu-yu. In animal models, its mode of action is suggested to be via stimulating endogenous CGRP release via activation of vanilloid receptor subtype $1 .^{28,29}$ Whether rutaecarpine causes similar effects as CGRP in human radial arteries is the focus of ongoing studies.
The precise mechanisms that regulate the expression and release of CGRP are unknown. However, several different classes of regulatory factors act to modulate CGRP synthesis and release by antagonizing or activating nerve growth factor. ${ }^{30}$ As CGRP is released directly onto the smooth muscle cell layer from the innervation into the wall, the physiologic concentration of CGRP at the site of action is many times greater than the picomolar plasma concentration observed in healthy human volunteers. ${ }^{31}$ It is generally considered that the levels of CGRP detected in plasma are likely to be due to leakage after localized release rather than a specific systemic function. As well, although CGRP is widely established as a potent vasodilator, its exact mechanism of action remains unclear. There are currently two modes of action, endothelium dependent and endothelium independent. ${ }^{32}$ The endothelium-dependent pathway suggests that CGRP activity is mediated via the production of endothelial NO, which then relaxes vascular smooth muscle cells. ${ }^{32}$ The endothelium-independent pathway proposes that CGRP directly 
binds to receptors on the smooth muscle cells and is coupled to production of cyclic adenosine monophosphate by adenylate cyclase. The increase in intracellular cyclic adenosine monophosphate concentration stimulates protein kinase A, and this opens $\mathrm{K}^{+}$channels and activates calcium sequestration mechanisms to cause smooth muscle cell relaxation. ${ }^{32}$ The majority of data from studies involving rat, human, and porcine tissues suggest that CGRP can cause vasodilation in the absence of an endothelium, thereby supporting the role of an endothelium-independent pathway. ${ }^{32,33}$ Conversely, studies have also shown that NO synthase inhibitor blocks CGRP activity in the rat aorta, rat pulmonary artery, and human internal thoracic artery, suggesting CGRP-mediated vasodilation is dependent on the presence of $\mathrm{NO}$ and therefore the endothelium. ${ }^{34-36}$ In our study, blocking NO synthesis with L-NAME, a NO synthase inhibitor, did not affect CGRP-induced vasodilation, suggesting that CGRP is able to act via a pathway independent of the endothelium or NO. Therefore, this result supports the notion that in human radial arteries, CGRP activity might be mediated by an endothelium-independent pathway. It is difficult to speculate as to why the internal thoracic artery and radial artery respond differently to CGRP, although it could be associated with the increased wall thickness and intimal thickening of radial arteries. ${ }^{1}$ However, we show clear evidence that CGRP can induce vasodilation in the presence of calcium-activated $\mathrm{K}^{+}$channel blockade, voltage-dependent $\mathrm{K}^{+}$channel blockade, but not with inwardly rectifying $\mathrm{K}^{+}$channel blockade (Kir), suggesting that a possible mechanism of action for CGRP is by opening the Kir channel. Our data suggest that the development of potassium channel openers could be a new avenue for the treatment of radial arteries before bypass surgery to impair spasm and lessen postoperative risk. Furthermore, the radial arteries used in this study did not respond to acetylcholine-mediated vasodilation (results not shown), indicating that a functional endothelium is not necessary for CGRP function.

In conclusion, this study has demonstrated that CGRP decreased the basal arterial tone in human radial arteries and, when challenged with ang II, CGRP significantly inhibited ang II-induced vasoconstriction in a dose-dependent manner. Inhibition of the Kir channel completely impaired the effects of CGRP, indicating an endothelium-independent mechanism for the actions of CGRP and is thus possibly more effective in diseased human vessels with underlying endothelial dysfunction.

\section{References}

1. Ruengsakulrach P, Sinclair R, Komeda M, Raman J, Gordon I, Buxton B. Comparative histopathology of radial artery versus internal thoracic artery and risk factors for development of intimal hyperplasia and atherosclerosis. Circulation. 1999;100(19 Suppl):II139-44.

2. de Gasparo M, Catt KJ, Inagami T, Wright JW, Unger T. International Union of Pharmacology. XXIII. The angiotensin II receptors. Pharmacol Rev. 2000;52:415-72.
3. Yoshimoto R, Mitsui-Saito M, Ozaki H, Karaki H. Effects of adrenomedullin and calcitonin gene-related peptide on contractions of the rat aorta and porcine coronary artery. Br J Pharmacol. 1998;123:1645-54.

4. Tippins JR. CGRP: a novel neuropeptide from the calcitonin gene is the most potent vasodilator known. J Hypertens Suppl. 1986;4:S102-5.

5. Wimalawansa SJ. Amylin, calcitonin gene-related peptide, calcitonin, and adrenomedullin: a peptide superfamily. Crit Rev Neurobiol. 1997; $11: 167-239$

6. Li J, Wang DH. Development of angiotensin II-induced hypertension: role of CGRP and its receptor. J Hypertens. 2005;23:113-8.

7. Rosenfeld MG, Mermod JJ, Amara SG, Swanson LW, Sawchenko PE, Rivier J, et al. Production of a novel neuropeptide encoded by the calcitonin gene via tissue-specific RNA processing. Nature. 1983;304:129-35.

8. Amara SG, Arriza JL, Leff SE, Swanson LW, Evans RM, Rosenfeld MG. Expression in brain of a messenger RNA encoding a novel neuropeptide homologous to calcitonin gene-related peptide. Science. 1985;229:1094-7.

9. Wimalawansa SJ, Morris HR, Etienne A, Blench I, Panico M, MacIntyre I. Isolation, purification and characterization of beta-hCGRP from human spinal cord. Biochem Biophys Res Commun. 1990;167: 993-1000.

10. Du YH, Peng J, Huang ZZ, Jiang DJ, Deng HW, Li YJ. Delayed cardioprotection afforded by nitroglycerin is mediated by alpha-CGRP via activation of inducible nitric oxide synthase. Int J Cardiol. 2004;93:49-54.

11. Wang W, Sun W, Wang X. Intramuscular gene transfer of CGRP inhibits neointimal hyperplasia after balloon injury in the rat abdominal aorta. Am J Physiol Heart Circ Physiol. 2004;287:H1582-9.

12. Li Y, Fiscus RR, Wu J, Yang L, Wang X. The antiproliferative effects of calcitonin gene-related peptide in different passages of cultured vascular smooth muscle cells. Neuropeptides. 1997;31:503-9.

13. Chowdhury UK, Airan B, Mishra PK, Kothari SS, Subramaniam GK, Ray R, et al. Histopathology and morphometry of radial artery conduits: basic study and clinical application. Ann Thorac Surg. 2004;78:1614-21.

14. Hamilton CA, Berg G, McIntyre M, McPhaden AR, Reid JL, Dominiczak AF. Effects of nitric oxide and superoxide on relaxation in human artery and vein. Atherosclerosis. 1997;133:77-86.

15. He GW, Yang CQ. Comparative study on calcium channel antagonists in the human radial artery: clinical implications. $J$ Thorac Cardiovasc Surg. 2000;119:94-100.

16. He GW, Angus JA, Rosenfeldt FL. Reactivity of the canine isolated internal mammary artery, saphenous vein, and coronary artery to constrictor and dilator substances: relevance to coronary bypass graft surgery. J Cardiovasc Pharmacol. 1988;12:12-22.

17. Petersen KA, Lassen LH, Birk S, Lesko L, Olesen J. BIBN4096BS antagonizes human alpha-calcitonin gene related peptide-induced headache and extracerebral artery dilatation. Clin Pharmacol Ther. 2005; 77:202-13.

18. Harrison WE, Mellor AJ, Clark J, Singer DR. Vasodilator pre-treatment of human radial arteries: comparison of effects of phenoxybenzamine vs papaverine on norepinephrine-induced contraction in vitro. Eur Heart J. 2001;22:2209-16.

19. Chrissobolis S, Ziogas J, Chu Y, Faraci FM, Sobey CG. Role of inwardly rectifying $\mathrm{K}(+)$ channels in $\mathrm{K}(+)$-induced cerebral vasodilatation in vivo. Am J Physiol Heart Circ Physiol. 2000;279:H2704-12.

20. Sobey CG. Potassium channel function in vascular disease. Arterioscler Thromb Vasc Biol. 2001;21:28-38.

21. Portaluppi F, Vergnani L, Margutti A, Ambrosio MR, Bondanelli M, Trasforini G, et al. Modulatory effect of the renin-angiotensin system on the plasma levels of calcitonin gene-related peptide in normal man. J Clin Endocrinol Metab. 1993;77:816-20.

22. Fujioka S, Sasakawa O, Kishimoto H, Tsumura K, Morii H. The antihypertensive effect of calcitonin gene-related peptide in rats with norepinephrine- and angiotensin II-induced hypertension. $J$ Hypertens. 1991;9:175-9.

23. Itabashi A, Kashiwabara H, Shibuya M, Tanaka K, Masaoka H, Katayama S, et al. The interaction of calcitonin gene-related peptide with angiotensin II on blood pressure and renin release. J Hypertens Suppl. 1988;6:S418-20.

24. Kawasaki H, Inaizumi K, Nakamura A, Hobara N, Kurosaki Y. Chronic angiotensin II inhibition increases levels of calcitonin gene-related 
peptide mRNA of the dorsal root ganglia in spontaneously hypertensive rats. Hypertens Res. 2003;26:257-63.

25. Li J, Zhao H, Supowit SC, DiPette DJ, Wang DH. Activation of the renin-angiotensin system in alpha-calcitonin gene-related peptide/calcitonin gene knockout mice. J Hypertens. 2004;22:1345-9.

26. Jernbeck J, Samuelson UE. Effects of lidocaine and calcitonin generelated peptide (CGRP) on isolated human radial arteries. $J$ Reconstr Microsurg. 1993;9:361-5.

27. Qin XP, Ye F, Liao DF, Li YJ. Involvement of calcitonin gene-related peptide in the depressor effects of losartan and perindopril in rats. Eur J Pharmacol. 2003;464:63-7.

28. Deng PY, Ye F, Cai WJ, Tan GS, Hu CP, Deng HW, et al. Stimulation of calcitonin gene-related peptide synthesis and release: mechanisms for a novel antihypertensive drug, rutaecarpine. J Hypertens. 2004;22: $1819-29$.

29. Hu CP, Xiao L, Deng HW, Li YJ. The depressor and vasodilator effects of rutaecarpine are mediated by calcitonin gene-related peptide. Planta Med. 2003;69:125-9.

30. Deng PY, Li YJ. Calcitonin gene-related peptide and hypertension. Peptides. 2005;26:1676-85.
31. Girgis SI, Macdonald DW, Stevenson JC, Bevis PJ, Lynch C, Wimalawansa SJ, et al. Calcitonin gene-related peptide: potent vasodilator and major product of calcitonin gene. Lancet. 1985;2:14-6.

32. Brain SD, Grant AD. Vascular actions of calcitonin gene-related peptide and adrenomedullin. Physiol Rev. 2004;84:903-34.

33. Bell D, McDermott BJ. Calcitonin gene-related peptide in the cardiovascular system: characterization of receptor populations and their (patho)physiological significance. Pharmacol Rev. 1996;48:253-88.

34. Raddino R, Pela G, Manca C, Barbagallo M, D’Aloia A, Passeri M, et al. Mechanism of action of human calcitonin gene-related peptide in rabbit heart and in human mammary arteries. J Cardiovasc Pharmacol. 1997; 29:463-70.

35. Gray DW, Marshall I. Nitric oxide synthesis inhibitors attenuate calcitonin gene-related peptide endothelium-dependent vasorelaxation in rat aorta. Eur J Pharmacol. 1992;212:37-42.

36. Wisskirchen FM, Burt RP, Marshall I. Pharmacological characterization of CGRP receptors mediating relaxation of the rat pulmonary artery and inhibition of twitch responses of the rat vas deferens. Br J Pharmacol. 1998;123:1673-83.

\section{JTCVS On-Line Manuscript Submission and Review}

The Journal of Thoracic and Cardiovascular Surgery requires authors and reviewers to submit all new and revised manuscripts and reviews via Editorial Manager. Point your browser to http://jtcvs.editorialmanager.com, log in as author or reviewer (as appropriate), and follow the instructions provided.

To retrieve your username and password, click "Forget your password?" on the Editorial Manager log-in page.

If you have questions or experience problems uploading your manuscript or review, please contact the editorial office:

Telephone: 215-762-1854

E-mail: jtcvs@drexelmed.edu 